\title{
Experimental Relaxation Behaviour of Chopped-Strand Mat Glass Fibre Reinforced Polyester Beams in Three Point Bending
}

\author{
S. Y. Zhang \\ Institute of Mechanics, Chinese Academy of Science, Beijing, China \\ and \\ R. Kitching \\ Mechanical Engineering Department, UMIST, Manchester, UK
}

\begin{abstract}
An experimental study of the relaxation behaviour of beams consisting of chopped-strand mat glass fibre reinforced polyester (CSM-GRP) beams under three point bending was carried out on twelve specimens cut from a sheet of laminate constructed by hand lay-up. Other preliminary tests were conducted to commission the rig, where a beam specimen was loaded through a screw system to give a fixed deflexion. The load and the bending strains were then measured continuously. Marked reductions of load and bending strains were seen in the tests, where the period of relaxation varied by up to 97 hours. A preliminary model with a time-dependent transverse shear modulus was proposed to represent load and strain relaxation behaviour. Some success was achieved, but strain behaviour at the two surfaces was different and is so far unexplained.
\end{abstract}

\section{NOTATION}

$a \quad$ half span of beam specimen

$A$ area of cross-section of beam specimen

E Young's modulus

$f \quad$ beam deflexion

$G_{13} \quad$ through-thickness shear modulus (modulus of rigidity)

Composite Structures 0265-931X/87/\$03.50 C Elsevier Applied Science Publishers Ltd, England, 1987. Printed in Great Britain 
$G_{13.1} \quad$ initial shear modulus

$G_{1.3}(t) \quad$ relaxation modulus (or time-dependent modulus)

$h \quad$ thickness of beam specimen

I second moment of area of beam cross-section about neutral axis of bending

$k \quad$ a constant factor in eqn (10)

$Q \quad$ load on beam

$Q(t) \quad$ relaxation load

$t$ time (in minutes or hours) or duration of relaxation

$w \quad$ width of beam specimen

$\alpha \quad$ a constant factor in the following formula:

$G_{13}(t)=G_{13,1} \mathrm{e}^{-\kappa t}$

(where the dimension of $\alpha$ is $\mathrm{min}^{-1}$ )

$\epsilon_{\mathrm{c}} \quad$ compressive strain

$\epsilon_{1} \quad$ initial strain

$\epsilon_{t} \quad$ relaxation strain

$\epsilon_{\mathrm{T}} \quad$ tension strain

$\phi \quad$ percentage reduction of relaxation of strain or load,

e.g. $\phi=\frac{\left(\epsilon_{\mathrm{I}}-\epsilon_{t}\right)}{\epsilon_{\mathrm{I}}} 100 \%$

$\phi \quad$ average relaxation rate within a certain period of time $(=\phi / t)$

$\nu \quad$ Poisson's ratio

For directions 1, 2, 3 see Fig. 2

\section{INTRODUCTION}

Chopped-strand mat glass fibre reinforced polyester (CSM-GRP) is now widely used in the chemical and process industries for pressure vessel and pipeline systems where corrosive environments occur. The present study is concerned with laminate made by hand lay-up with glass supplied in the form of chopped-strand mat (CSM). Creep and relaxation phenomena have been observed in the bending tests of pipe bends made in this way. ${ }^{1}$ In order to characterize the relaxation (or creep) behaviour of this kind of material, relaxation experiments were conducted on beams of the same type of material under three point bending in the same ambient environment as that in which the pipe bends were tested. In the test procedure the beam specimen was loaded by a screwed bar until the bending strains reached predetermined values, after which the deflexion was kept constant, and the load and strains were measured continuously. Twelve specimens 
were tested, and the results show similar relaxation phenomena to those which arose in the pipe bend tests.

To explore the relaxation mechanism, a finite element method (FEM) computation was conducted. Using experimental data and the FEM results, a simple relaxation model involving a time-dependent transverse shear modulus was proposed.

\section{EXPERIMENTAL DETAILS}

\subsection{Specimens}

The material tested was E-glass fibre CSM reinforced by polyester resin Atlac 382.05 which has a strain to failure of $3.6 \%$ to $4.2 \%$. A laminate panel was made commercially, using a flat sheet of glass for hand lay-up purposes. The method adopted was identical to that used for flat coupons manufactured in the same manner and at the same time as pipes for purposes of material testing. A typical wall construction is shown in Fig. 1.

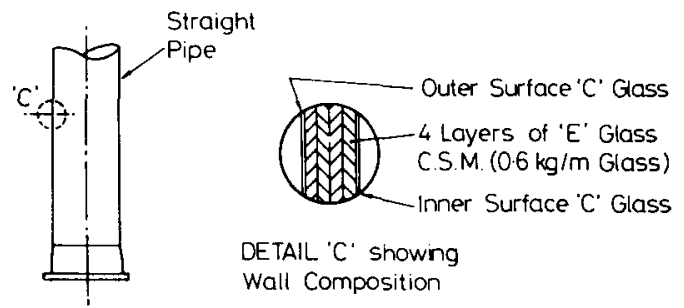

Fig. 1. Typical GRP pipe wall construction.

This results in a resin-rich layer and a smooth surface on one side (equivalent to the inside of the pipe) and a somewhat less resin-rich layer on the other side (equivalent to the outside of the pipe), which is undulating.

Seventeen specimens were cut from the panel by an electric saw, and ground to have uniform width. The thickness and width were measured by a micrometer at a number of points, and mean values are given in Table 1 . A noticeable nonuniformity of the thickness was seen for some specimens. All the specimens tested were instrumented with two strain gauges measuring longitudinal strain on both surfaces in a three point bending arrangement. The positions of the two gauges were $5 \mathrm{~mm}$ from the centre of the span $(126 \mathrm{~mm})$ so as not to coincide with the central loading point (see Fig. 2). The strain gauges had a gauge length of $2 \mathrm{~mm}$ and a gauge factor of $2 \cdot 1$. 
TABLE 1

Specimen Details

\begin{tabular}{|c|c|c|c|c|c|c|}
\hline $\begin{array}{c}\text { Specimen } \\
\text { No. }\end{array}$ & $\begin{array}{c}\text { Thickness } \\
h(\mathrm{~mm})\end{array}$ & $\begin{array}{c}\text { Width } \\
w(\mathrm{~mm})\end{array}$ & $\begin{array}{c}\text { Initial } \\
\text { deflexion } \\
f(\mathrm{~mm})\end{array}$ & $\begin{array}{c}\text { Maximum } \\
\text { load } \\
Q(\mathrm{kgf})\end{array}$ & $\begin{array}{l}\text { Duration } \\
\text { of relax. } \\
t(\mathrm{~h})\end{array}$ & Remarks \\
\hline 1 & $8 \cdot 90$ & $20 \cdot 50$ & & & & Preliminary \\
\hline 2 & $7 \cdot 64$ & $25 \cdot 55$ & $5 \cdot 45$ & $81 \cdot 25$ & 27 & \\
\hline 3 & $9 \cdot 30$ & $21 \cdot 35$ & & & & Preliminary \\
\hline 4 & $8 \cdot 00$ & 23.65 & $4 \cdot 44$ & 64.89 & 24 & \\
\hline 5 & $8 \cdot 10$ & $22 \cdot 80$ & & & & Preliminary \\
\hline 6 & $8 \cdot 13$ & $22 \cdot 84$ & & & & Preliminary \\
\hline 7 & $9 \cdot 00$ & $22 \cdot 98$ & $1 \cdot 26$ & $29 \cdot 10$ & 46 & \\
\hline 8 & 8.60 & $22 \cdot 25$ & $2 \cdot 60$ & $45 \cdot 50$ & $96 \cdot 5$ & \\
\hline 9 & 8.05 & $22 \cdot 91$ & $4 \cdot 45$ & $62 \cdot 50$ & 72 & \\
\hline 10 & $9 \cdot 17$ & $23 \cdot 03$ & $2 \cdot 77$ & $66 \cdot 10$ & 44 & \\
\hline 11 & 8.95 & $22 \cdot 68$ & $2 \cdot 81$ & $56 \cdot 40$ & 71 & \\
\hline 12 & $7 \cdot 98$ & $22 \cdot 74$ & 3.66 & 56.90 & 97 & Battery change \\
\hline 13 & $9 \cdot 12$ & $23 \cdot 68$ & $3 \cdot 26$ & $55 \cdot 20$ & $49 \cdot 5$ & \\
\hline 14 & $8 \cdot 10$ & $23 \cdot 15$ & $5 \cdot 18$ & $81 \cdot 25$ & $71 \cdot 5$ & \\
\hline 15 & $8 \cdot 28$ & $22 \cdot 97$ & 1.59 & $27 \cdot 32$ & 72 & \\
\hline 16 & $8 \cdot 20$ & $22 \cdot 55$ & $1 \cdot 56$ & $29 \cdot 70$ & 72 & \\
\hline 17 & $9 \cdot 21$ & $21 \cdot 84$ & $1 \cdot 28$ & $26 \cdot 70$ & 43 & \\
\hline
\end{tabular}

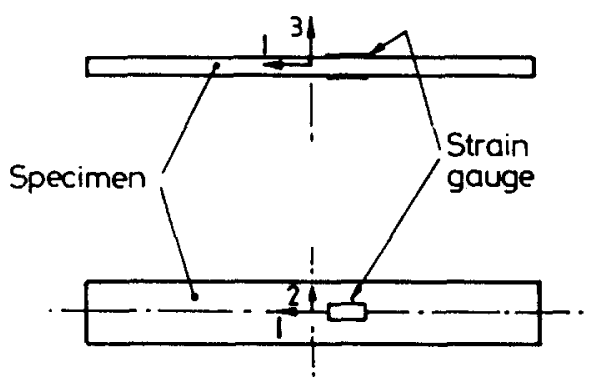

Fig. 2. Strain gauge positions.

\subsection{Test rig and instrumentation}

The experimental set-up is shown schematically in Fig. 3. The specimen was supported on two lower anvils and loaded through an upper anvil by a screw bar, with a strain gauge load cell being connected in line between the upper anvil and the screw bar.

Three strain indicators were used to measure load and the bending strains separately. The three units were: a 'Peekel Strain Indicator Type 


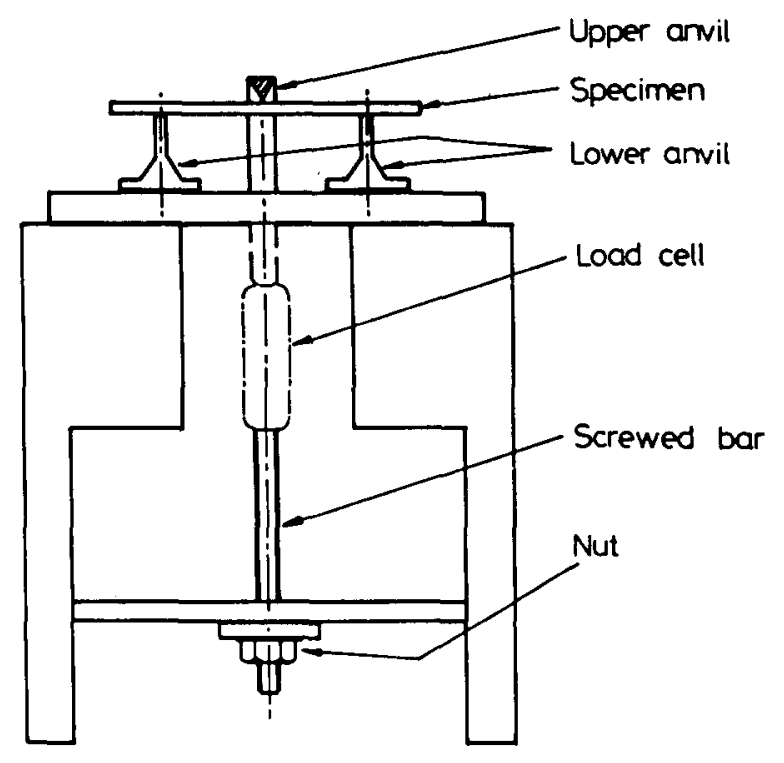

Fig. 3. Test rig.

CA660', for measuring the load via the load cell; and a 'Peekel Strain Indicator Type 581 DNH' and a 'Vishay Strain Gauge Indicator P-3500', for measuring the tensile and compressive surface strains, respectively.

Before the formal tests, some preliminary tests were done to check the instruments, and these included calibration of the strain gauge load cell, which was in the form of a tensile strip. Drift tests over a period of several days were conducted. A precise resistor was connected to the strain indicator, and the reading was monitored continuously. The stability of each unit was assumed satisfactory when the drift was limited to $8 \times 10^{-6}$ to $10 \times 10^{-6}$ strain over a period of 24 hours. It was found that using three channels of one strain indicator for the three quantities being measured in the relaxation tests was unsatisfactory, because switching from one channel to another caused some discontinuity in the reading, presumably because of the change of contact resistance of the switch.

\subsection{Experimental procedure}

The following procedure was followed.

(a) The specimen was positioned on the top of the two lower anvils, but the upper anvil was above the specimen and not touching it. Zero readings were taken from all three strain indicators. 
(b) The upper anvil was lowered, and positioned at the centre of the specimen. A thin felt insert was positioned between the knife edge and the specimen to prevent the knife edge from indenting the specimen. The rig's dead weight of $5.5 \mathrm{kgf}$ was applied to the specimen.

(c) The dial gauge on the top of the upper anvil was set, and its initial reading taken. The three strain indicators (one for load, one for tensile bending strain, one for compressive bending strain) were then read.

(d) The specimen was loaded through the screw step by step by controlling the deflexion. The increment of the deflexion in each step amounted to one or two revolutions of the needle of the dial gauge, one revolution of the needle being equivalent to $0.254 \mathrm{~mm}$. The applied deflexion was finally made to correspond to the bending strains required for the particular test.

(e) In the first hour of the relaxation process, readings were taken every 5 or 10 minutes. After one hour, the time interval for taking the readings was progressively longer. The date, time, temperature and humidity were also noted along with the strain readings. The duration of the relaxation tests varied between 2 and 4 days.

(f) On termination of the relaxation test, the specimen was unloaded in decrements.

(g) Finally the dial gauge was removed, the upper anvil lifted, and the specimen left to recover with no load on it other than its own weight.

(h) The duration of the recovery was between 1 and 10 hours. The readings of the residual strains were finally taken to complete the test.

\section{EXPERIMENTAL RESULTS AND DISCUSSION}

Of the 17 specimens, 5 were used for the preliminary tests, and the other 12 were used for complete relaxation tests. According to the maximum initial bending strains applied, the 12 specimens were divided into 3 groups as shown in Table 2. Each group can also be separated into two sub-groups. In one sub-group the specimen was tested with the smooth surface in compression (uppermost) and the undulating surface in tension, whereas the other sub-group was tested in the opposite sense (i.e. undulating surface uppermost). Figure 4 shows schematically the whole process for the test on specimen No. 11 as typical of the behaviour of all specimens. The plots illustrate the variations of deflexion, load and strains with time. For convenience the time coordinate (abscissa) has a different scale for the different intervals of time.

A noticeable feature of Fig. 4 is that in the relaxation process the tensile strain of the undulating surface reduced far more than the compressive 
TABLE 2

Grouping of Specimens

\begin{tabular}{|c|c|c|c|c|}
\hline \multirow[b]{2}{*}{$\begin{array}{l}\text { Group } \\
\text { No. }\end{array}$} & \multirow[b]{2}{*}{$\begin{array}{c}\text { Specimen } \\
\text { No. }\end{array}$} & \multirow{2}{*}{$\begin{array}{c}\text { Maximum } \\
\text { initial } \\
\text { bending strain } \\
\left(10^{-6} \mathrm{~m} / \mathrm{m}\right)\end{array}$} & \multicolumn{2}{|c|}{ Test configuration } \\
\hline & & & $\begin{array}{l}\text { Undulating } \\
\text { surface } \\
\text { in tension }\end{array}$ & $\begin{array}{c}\text { Smooth surface } \\
\text { in tension }\end{array}$ \\
\hline \multirow{5}{*}{1} & 15 & \multirow{5}{*}{$3000-4000$} & Yes & No \\
\hline & 16 & & Yes & No \\
\hline & & & & \\
\hline & 17 & & No & Yes \\
\hline & 7 & & No & Yes \\
\hline \multirow{5}{*}{2} & 10 & \multirow{5}{*}{$6000-7000$} & Yes & No \\
\hline & 11 & & Yes & No \\
\hline & & & & \\
\hline & 8 & & No & Yes \\
\hline & 13 & & No & Yes \\
\hline \multirow{5}{*}{3} & 4 & \multirow{5}{*}{$10000-13000$} & Yes & No \\
\hline & 14 & & Yes & No \\
\hline & & & & \\
\hline & 2 & & No & Yes \\
\hline & 9 & & No & Yes \\
\hline
\end{tabular}
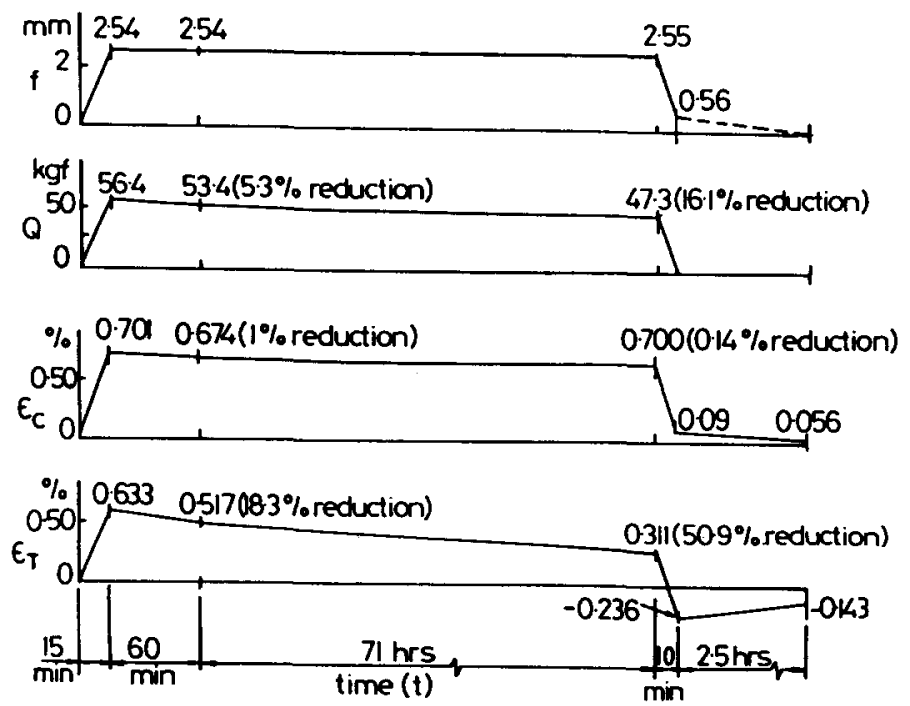

Fig. 4. Plots of deflection, load and strains with time, Specimen No. 11. 
TABLE 3

Maximum Initial Strains

\begin{tabular}{|c|c|c|c|c|c|c|}
\hline \multirow[b]{2}{*}{$\begin{array}{l}\text { Specimen } \\
\text { No. }\end{array}$} & \multicolumn{2}{|c|}{$\begin{array}{l}\text { Maximum tensile } \\
\operatorname{strain}\left(10^{-6} \mathrm{~m} / \mathrm{m}\right)\end{array}$} & \multicolumn{2}{|c|}{$\begin{array}{l}\text { Maximum compressive } \\
\text { strain }\left(10^{-6} \mathrm{~m} / \mathrm{m}\right)\end{array}$} & \multicolumn{2}{|c|}{$\begin{array}{c}\text { Percentage by which } \\
\text { undul. strain is } \\
\text { less than smooth } \\
\text { strain }\end{array}$} \\
\hline & Undul. & Smooth & Undul. & Smooth & $\begin{array}{l}\text { Smooth } \\
\text { in } \\
\text { tension }\end{array}$ & $\begin{array}{l}\text { Undul. } \\
\text { in } \\
\text { tension }\end{array}$ \\
\hline 15 & 3202 & & & 3767 & & 15 \\
\hline 16 & 3655 & & & 4005 & & $8 \cdot 7$ \\
\hline 7 & & 3380 & 3391 & & $-0 \cdot 3$ & \\
\hline 17 & & 3773 & 3242 & & $14 \cdot 1$ & \\
\hline 10 & 6360 & & & 7269 & & $12 \cdot 5$ \\
\hline 11 & 6334 & & & 7010 & & $9 \cdot 6$ \\
\hline 8 & & 6640 & 6618 & & $0 \cdot 33$ & \\
\hline 13 & & 6603 & 6302 & & $4 \cdot 56$ & \\
\hline 4 & 10153 & & & 10774 & & $5 \cdot 8$ \\
\hline 14 & 10345 & & & 13229 & & $21 \cdot 8$ \\
\hline 2 & & 13644 & 12128 & & $11 \cdot 1$ & \\
\hline 9 & & 12500 & 10459 & & $16 \cdot 3$ & \\
\hline
\end{tabular}

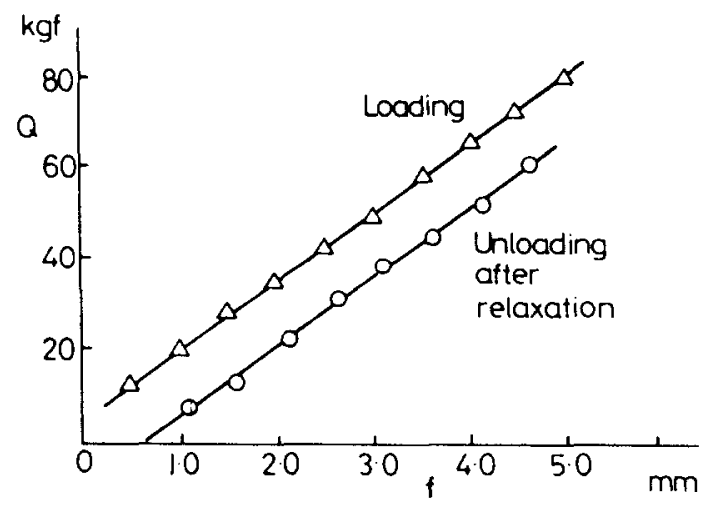

Fig. 5. Variation of load with deflection, Specimen No. 2. 


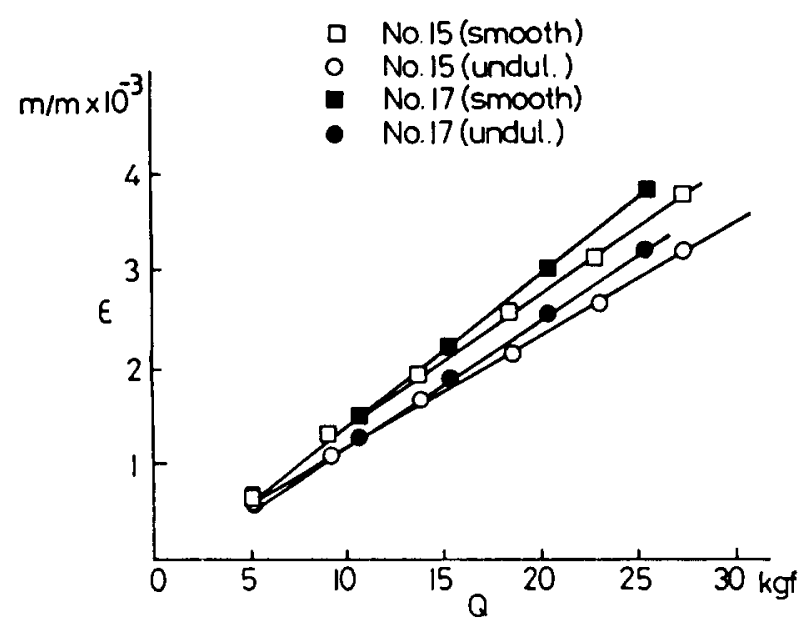

Fig. 6. Variation of strains with load, Specimen Nos 15, 17.

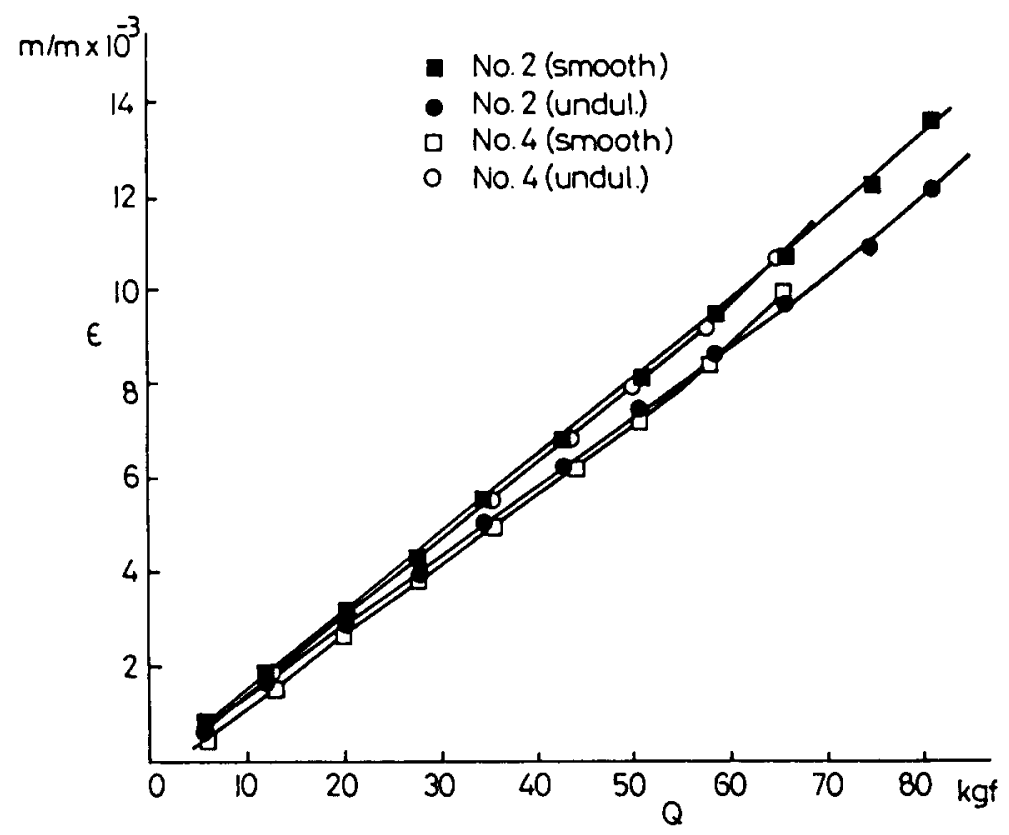

Fig. 7. Variation of strains with load, Specimen Nos 2, 4 .

strain of the smooth surface; during unloading after relaxation, the tensile strain of the undulating surface changed sense, so that the strains on the two surfaces had the same sense after unloading. In the recovery process the strains decreased gradually to small values.

The bending behaviour in the loading process (together with the unloading process) is shown in Table 3 and Figures 5, 6 and 7. It can be 
TABLE 4

Experimental Results—Load Relaxation

\begin{tabular}{|c|c|c|c|c|c|c|c|}
\hline \multirow[b]{3}{*}{$\begin{array}{c}\text { Specimen } \\
\text { No. }\end{array}$} & \multirow{3}{*}{$\begin{array}{c}\text { Maximum } \\
\text { load } \\
Q_{\max } \\
\text { (kgf) }\end{array}$} & \multicolumn{6}{|c|}{ Load relaxation } \\
\hline & & \multicolumn{3}{|c|}{ Short-term } & \multicolumn{3}{|c|}{ Long-term } \\
\hline & & $\begin{array}{l}\text { Time } \\
(\mathrm{min})\end{array}$ & $\begin{array}{l}\text { Reduction } \\
(\%)\end{array}$ & $\begin{array}{c}\text { Relax. } \\
\text { rate } \\
(\% / \mathrm{h})\end{array}$ & $\begin{array}{c}\text { Time } \\
\text { (h) }\end{array}$ & $\begin{array}{c}\text { Reduction } \\
(\%)\end{array}$ & $\begin{array}{c}\text { Relax. } \\
\text { rate } \\
(\% / \mathrm{h})\end{array}$ \\
\hline 15 & $27 \cdot 32$ & 85 & $6 \cdot 7$ & $4 \cdot 7$ & 72 & $13 \cdot 3$ & $0 \cdot 18$ \\
\hline 16 & $29 \cdot 70$ & 60 & $3 \cdot 0$ & $3 \cdot 0$ & 72 & $14 \cdot 5$ & $0 \cdot 20$ \\
\hline 7 & $29 \cdot 10$ & 60 & $6 \cdot 2$ & $6 \cdot 2$ & 46 & $20 \cdot 6$ & 0.44 \\
\hline 17 & $26 \cdot 70$ & 60 & $5 \cdot 6$ & $5 \cdot 6$ & 43 & $9 \cdot 0$ & $0 \cdot 21$ \\
\hline 10 & $66 \cdot 10$ & 60 & $5 \cdot 9$ & 5.9 & 44 & $13 \cdot 8$ & $0 \cdot 31$ \\
\hline 11 & $56 \cdot 40$ & 60 & $5 \cdot 3$ & $5 \cdot 3$ & 71 & $16 \cdot 1$ & $0 \cdot 23$ \\
\hline 8 & $45 \cdot 50$ & 85 & 7.9 & $5 \cdot 5$ & 96 & $17 \cdot 4$ & $0 \cdot 18$ \\
\hline 13 & $55 \cdot 20$ & 60 & $6 \cdot 5$ & $6 \cdot 5$ & $49 \cdot 5$ & $17 \cdot 6$ & $0 \cdot 36$ \\
\hline 4 & $64 \cdot 89$ & 60 & $5 \cdot 6$ & $5 \cdot 6$ & & & \\
\hline 14 & $81 \cdot 25$ & 45 & $7 \cdot 8$ & $9 \cdot 8$ & $71 \cdot 5$ & $14 \cdot 5$ & $0 \cdot 20$ \\
\hline 9 & $62 \cdot 50$ & 60 & $5 \cdot 4$ & $5 \cdot 4$ & 72 & $15 \cdot 5$ & $0 \cdot 22$ \\
\hline \multirow[t]{2}{*}{2} & $81 \cdot 25$ & 70 & $7 \cdot 4$ & $6 \cdot 3$ & 27 & $15 \cdot 0$ & $0 \cdot 56$ \\
\hline & & \multicolumn{2}{|c|}{ Mean value } & $5 \cdot 8$ & & Mean value & $0 \cdot 28$ \\
\hline
\end{tabular}

seen that the bending strains were not symmetric with respect to the geometric neutral surface. For all specimens with the exception of specimen No. 7, the strain on the smooth surface was greater in magnitude than that of the undulating surface, no matter which surface was in tension or in compression. The plots of load versus deflexion in Fig. 5 are approximately linear in both loading and unloading processes; the gradient for loading is sensibly the same as that for unloading. Figures 6 and 7 show that when the strain is smaller than $0.6 \%$, the plot of load versus strain is linear, whereas when the strain is larger than $0.6 \%$, the plot exhibits nonlinearity.

The results of relaxation tests are summarized in Tables 4 and 5, and Figures 8,9 and 10. In the tables the percentage reduction of the strain due to relaxation within a certain time period was calculated as

$$
\phi=100\left(\epsilon_{\mathrm{I}}-\epsilon_{l}\right) / \epsilon_{\mathrm{I}}
$$

where $\epsilon_{\mathrm{I}}$ and $\epsilon_{t}$ are the initial strain and strain after relaxation, respectively. The average relaxation rate was given as

$$
\dot{\phi}=\phi / t
$$


TABLE 5

Experimental Results-Strain Relaxation

\begin{tabular}{|c|c|c|c|c|c|c|c|c|}
\hline \multirow{4}{*}{$\begin{array}{l}\text { Specimen } \\
\text { No. }\end{array}$} & \multirow{2}{*}{\multicolumn{2}{|c|}{$\begin{array}{c}\text { Maximum initial } \\
\text { strains } \\
\left(10^{-6} \mathrm{~m} / \mathrm{m}\right)\end{array}$}} & \multicolumn{6}{|c|}{ Relaxation of strains } \\
\hline & & & & hort-ter & & & ong-ter & \\
\hline & \multirow{2}{*}{$\begin{array}{l}\text { Tensile } \\
\text { strain }\end{array}$} & \multirow{2}{*}{$\begin{array}{c}\text { Compressive } \\
\text { strain }\end{array}$} & \multirow{2}{*}{$\begin{array}{l}\text { Time } \\
\text { (min) }\end{array}$} & \multicolumn{2}{|c|}{$\begin{array}{c}\text { Relax, rate } \\
(\% / \mathrm{h})\end{array}$} & \multirow{2}{*}{$\begin{array}{l}\text { Time } \\
\text { (h) }\end{array}$} & \multicolumn{2}{|c|}{$\begin{array}{c}\text { Relax. rate } \\
(\% / \mathrm{h})\end{array}$} \\
\hline & & & & Tens. & Comp. & & Tens. & Comp \\
\hline 15 & $\begin{array}{l}\text { Undul. } \\
3202 \\
\text { Undul. }\end{array}$ & $\begin{array}{l}\text { Smooth } \\
3767 \\
\text { Smooth }\end{array}$ & 85 & $25 \cdot 2$ & $0 \cdot 56$ & 72 & $0 \cdot 80$ & 0.04 \\
\hline 16 & $\begin{array}{c}3655 \\
\text { Smooth }\end{array}$ & $\begin{array}{r}4005 \\
\text { Undul. }\end{array}$ & 60 & $30 \cdot 0$ & 1.9 & 72 & 0.92 & 0.07 \\
\hline 7 & $\begin{array}{c}3380 \\
\text { Smooth }\end{array}$ & $\begin{array}{c}3391 \\
\text { Undul. }\end{array}$ & 60 & $3 \cdot 25$ & $2 \cdot 9$ & 46 & $0 \cdot 15$ & 0.43 \\
\hline 17 & 3773 & 3242 & 60 & $2 \cdot 65$ & $8 \cdot 6$ & 43 & $0 \cdot 15$ & $0 \cdot 38$ \\
\hline 10 & $\begin{array}{l}\text { Undul. } \\
6363 \\
\text { Undul. }\end{array}$ & $\begin{array}{l}\text { Smooth } \\
7269 \\
\text { Smooth }\end{array}$ & 60 & $23 \cdot 0$ & $0 \cdot 39$ & 44 & $1 \cdot 22$ & $0 \cdot 01$ \\
\hline 11 & $\begin{array}{c}6334 \\
\text { Smooth }\end{array}$ & $\begin{array}{c}7010 \\
\text { Undul. }\end{array}$ & 60 & $18 \cdot 3$ & $1 \cdot 0$ & 71 & $0 \cdot 72$ & 0.002 \\
\hline 8 & $\begin{array}{c}6640 \\
\text { Smooth }\end{array}$ & $\begin{array}{c}6618 \\
\text { Undul. }\end{array}$ & 85 & $1 \cdot 20$ & $3 \cdot 2$ & $96 \cdot 5$ & 0.07 & 0.44 \\
\hline 13 & 6603 & 6302 & 60 & $0 \cdot 53$ & $5 \cdot 0$ & $49 \cdot 5$ & 0.03 & $0 \cdot 76$ \\
\hline 4 & $\begin{array}{l}\text { Undul. } \\
10153 \\
\text { Undul. }\end{array}$ & $\begin{array}{l}\text { Smooth } \\
10774 \\
\text { Smooth }\end{array}$ & 60 & $11 \cdot 1$ & $0 \cdot 28$ & & & \\
\hline 14 & $\begin{array}{l}10345 \\
\text { Smooth }\end{array}$ & $\begin{array}{l}13229 \\
\text { Undul. }\end{array}$ & 45 & $33 \cdot 1$ & $0 \cdot 40$ & $71 \cdot 5$ & 0.69 & $0 \cdot 0$ \\
\hline 9 & $\begin{array}{l}12500 \\
\text { Smooth }\end{array}$ & $\begin{array}{l}10459 \\
\text { Undul. }\end{array}$ & 60 & 0.88 & $4 \cdot 5$ & 72 & $0 \cdot 04$ & $0 \cdot 77$ \\
\hline 2 & 13644 & 12128 & 70 & 0.43 & $10 \cdot 0$ & 27 & 0.02 & $1 \cdot 61$ \\
\hline & & \multicolumn{2}{|l|}{ Mean value } & \multicolumn{2}{|c|}{$7 \cdot 85$} & & \multicolumn{2}{|c|}{0.42} \\
\hline
\end{tabular}

The percentage reduction of load, and the average load relaxation rate, are calculated by similar expressions to eqns (1) and (2).

Analysing the results, the following remarks can be made.

(1) The relaxation rate of the strain at the undulating surface of the specimen is larger than that of the smooth surface of the specimen, no matter which surface is in tension or in compression. In particular, for the 


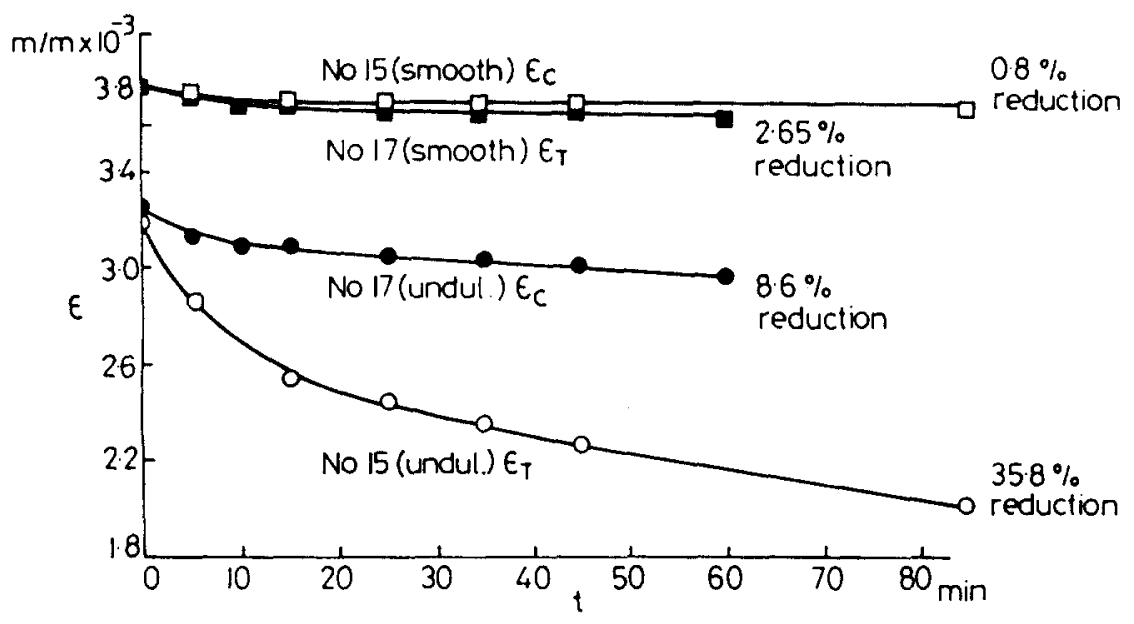

Fig. 8. Strain relaxation curves, Specimen Nos 15, 17.

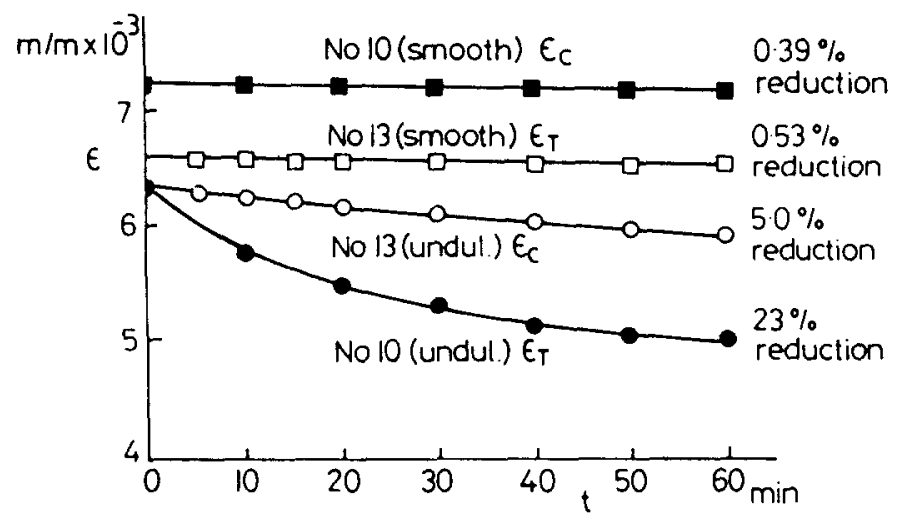

Fig. 9. Strain relaxation curves, Specimen Nos 10, 13.

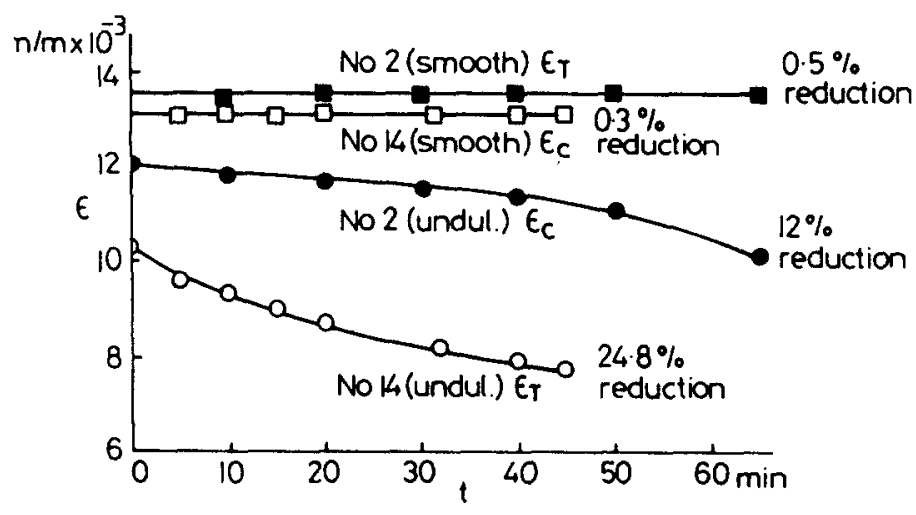

Fig. 10. Strain relaxation curves, Specimen Nos 2, 14. 
case where the undulating surface is in tension, the relaxation rate of the strain on the undulating surface is much larger than that on the smooth surface; when the smooth surface is in tension, the difference between the strain relaxation rates of the two surfaces is smaller than when the undulating surface is in tension. This phenomenon coincides with the observations in pipe bend tests ${ }^{1}$ under in-plane bending where flattening of a section, and hence shell bending, occurs. ${ }^{2}$

(2) Figures 8,9 and 10 show that the value of the initial bending strain has some effect on the shape of the relaxation curve for the strain on the undulating surface. When the initial strain is smaller than 0.01 , the strain relaxation rate of the undulating surface is a decreasing function of time; when the initial strain is larger than 0.01 , it becomes an increasing function within the time period of one minute. The initial strain has no significant effect on the relaxation rate of load.

(3) During relaxation tests, the deflexion of the beam specimens changed a little, because of the changes of temperature and hence load, and of the elasticity of the loading arrangement, but the change of deflexion was so small that the assumption of constant deflexion can reasonably be made.

(4) The ambient temperature had some effect on the relaxation rate. The temperature at night and at weekends (being $15^{\circ} \mathrm{C}$ to $16.5^{\circ} \mathrm{C}$ in January and February) was much lower than that in the normal working day $\left(20.5^{\circ} \mathrm{C}\right.$ to $\left.26^{\circ} \mathrm{C}\right)$. Consequently, the relaxation rate at night and at weekends was smaller than that during the working day. In spite of this, the results are still comparable in that all the specimens had some period in the daytime and some at night, while all initial and final times were in the daytime. As far as short-term relaxation is concerned, the comparability of the results is beyond question, because this period of time was always in daytime. There was no apparent effect of humidity, which fluctuated between $45 \%$ and $65 \%$.

\section{RELAXATION MODEL}

Explanation of the relaxation mechanism is now attempted, with reference to Fig. 11. During the relaxation process, it is assumed that the bending deflexion decreased gradually, while the shear deflexion increased at the same speed, so that the total deflexion remained constant. Because the transverse shear modulus $G_{13}$ (for directions 1, 2, 3 see Fig. 2) is governed by the resin matrix, it is assumed that during the process of relaxation it reduces gradually with time, resulting in shear plastic flow. If the shear flow increases, the bending strains would decrease, thus releasing the associated strain energy. 


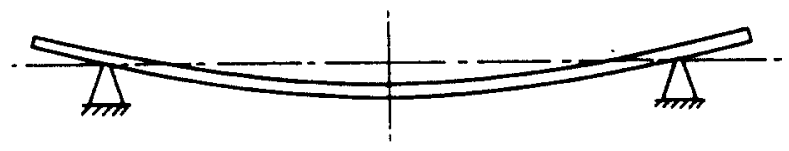

(a) Before relaxation

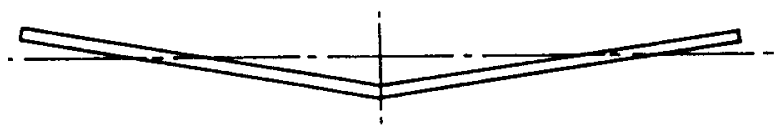

(b) After relaxation

Fig. 11. Relaxation mechanism: (a) beam before relaxation; (b) beam after relaxation.

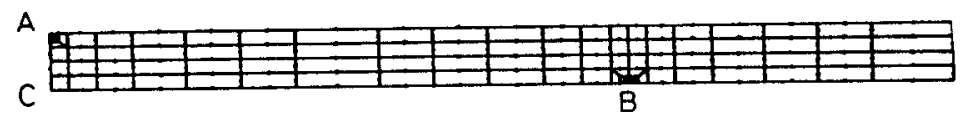

(a) Undeformed pattern
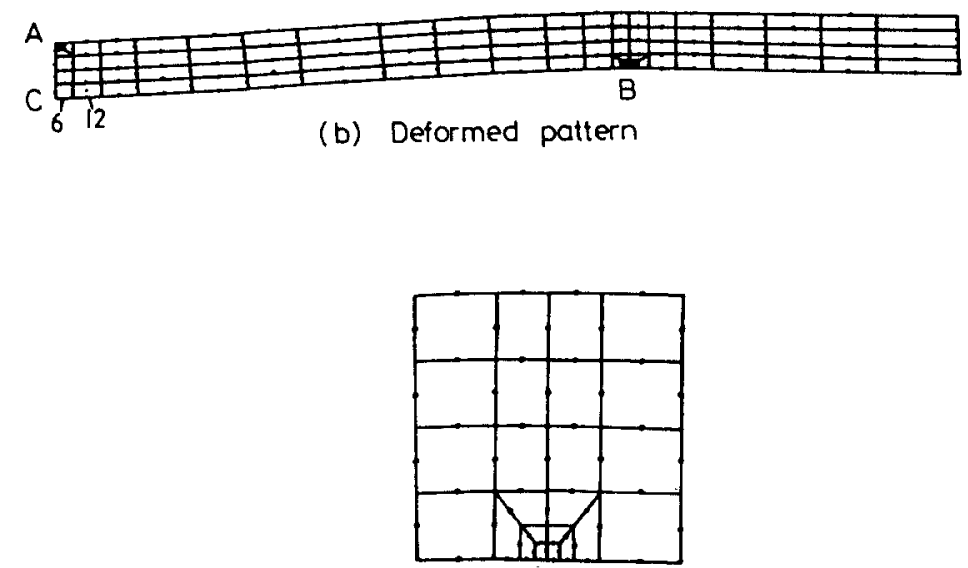

(c) Local enlargement

Fig. 12. Finite element mesh pattern: (a) undeformed; (b) deformed; (c) local enlargement at $\mathrm{B}$. 
On the basis of the concept described above, an FEM calculation was conducted. The two-dimensional 8-node quadrilateral isoparametric element was utilized. The finite element mesh pattern is shown in Fig. 12, where the right-hand half of the specimen only is considered. The assumed support condition is that point $B$ is fixed in the vertical direction, but it is free in the horizontal direction. The loading condition is that a constant ( 5 $\mathrm{mm}$ ) vertical deflexion is imposed on point $A$, the central point of the beam specimen. The symmetric displacement condition is imposed upon the nodal points on the symmetric line AC. The calculated deformed mesh pattern is shown in Fig. 12(b). Two kinds of material model were assumed: isotropic and orthotropic. Two different transverse shear moduli were used in the calculations, one being the initial modulus $G_{13, \mathrm{I}}$, and the other the relaxation modulus $G_{13}(t)$. We assume that $G_{13}(t)$ is equal to one tenth of $G_{13, \mathrm{I}}$. The material constants used in the calculation are from experimental results, ${ }^{3,4}$ and are given together with the calculated results of strains in element No. 6 and element No. 12 (see Fig. 12(b)) in Table 6. The strain values are the average strains for the two elements, respectively. The distance of the central point of element No. 12 from the central line of the beam $\mathrm{AC}$ is approximately $5 \mathrm{~mm}$.

The following can be seen from Table 6 .

(a) The normal strain of element No. 6 is larger than that of element No. 12 , whereas the opposite is true for the shear strains. The percentage reduction of the normal strain caused by the reduction of $G_{13}$ for element No. 12 is larger than that for element No. 6. For shear strain, the opposite is true, and the change is much more significant than the change in normal strain.

(b) When the shear modulus $G_{13}$ was reduced to one tenth of its initial value, the reduction of the normal strain of the element No. 12 was $21 \%$. This is for the orthotropic model which is more realistic than the isotropic model.

Using the relaxation mechanism assumed earlier in conjunction with the calculated results of FEM, the following relaxation model was proposed:

$$
G_{13}(t)=G_{13, \mathrm{I}} \mathrm{e}^{-\alpha t}
$$

where $\alpha$ is a constant to be determined.

From the test data in Table 5, the mean percentage reduction of the strain relaxation in the short-term relaxation was $7 \cdot 85 \%$ per hour; from FEM results of the orthotropic model in Table 6, we know that when $G_{13}(t)$ is equal to one tenth of $G_{13,1}$, the normal strain reduces by $21 \%$, which is 
TABLE 6

Computational Results of FEM

\begin{tabular}{|c|c|c|c|c|c|c|c|}
\hline \multirow[b]{2}{*}{$\begin{array}{c}\text { Material } \\
\text { model }\end{array}$} & \multirow{2}{*}{$\begin{array}{c}\text { Elastic } \\
\text { constants } \\
\text { (GPa) }\end{array}$} & \multirow[b]{2}{*}{$\begin{array}{l}\text { No. of } \\
\text { element }\end{array}$} & \multirow{2}{*}{$\begin{array}{c}\text { Shear } \\
\text { modulus } \\
G_{13}(\mathrm{GPa})\end{array}$} & \multicolumn{2}{|c|}{ Tensile strain } & \multicolumn{2}{|c|}{ Shear strain } \\
\hline & & & & $\begin{array}{l}\text { Value } \\
\left(10^{-6}\right)\end{array}$ & $\begin{array}{c}\text { Change } \\
(\%)\end{array}$ & $\begin{array}{l}\text { Value } \\
\left(10^{-6}\right)\end{array}$ & $\begin{array}{c}\text { Change } \\
(\%)\end{array}$ \\
\hline \multirow{3}{*}{ Isotropic } & \multirow{3}{*}{$E=7 \cdot 0$} & \multirow{3}{*}{6} & $2 \cdot 61$ & 11060 & \multirow{3}{*}{$-8 \cdot 0$} & 210 & \multirow{3}{*}{+2119} \\
\hline & & & & & & & \\
\hline & & & $0 \cdot 261$ & 10180 & & 4660 & \\
\hline \multirow{3}{*}{ material } & \multirow{3}{*}{$\nu=0.34$} & \multirow{3}{*}{12} & $2 \cdot 61$ & 10700 & & 540 & \multirow{3}{*}{+1024} \\
\hline & & & & & $-10 \cdot 2$ & & \\
\hline & & & $0 \cdot 261$ & 9610 & & 6070 & \\
\hline \multirow{3}{*}{ Orthotropic } & \multirow{3}{*}{$\begin{array}{l}E_{11}=E_{12} \\
=9 \cdot 81\end{array}$} & \multirow{3}{*}{6} & 1.43 & 10850 & \multirow{3}{*}{$-18 \cdot 8$} & 627 & \multirow{3}{*}{+1678} \\
\hline & & & & & & & \\
\hline & & & $0 \cdot 143$ & 8810 & & 11150 & \\
\hline \multirow{3}{*}{ material } & \multirow{3}{*}{$\begin{array}{l}\mathrm{E}_{33}=5 \cdot 203 \\
\nu_{13}=0 \cdot 34\end{array}$} & \multirow{3}{*}{12} & 1.43 & 10460 & \multirow{3}{*}{$-21 \cdot 0$} & 1410 & \multirow{3}{*}{+890} \\
\hline & & & & & & & \\
\hline & & & $0 \cdot 143$ & 8280 & & 13960 & \\
\hline
\end{tabular}

equivalent to the mean strain reduction measured in $160.5 \mathrm{~min}(60 \times 21 /$ 7.85). Thus, from eqn (3), we have

$$
\begin{aligned}
& 0 \cdot 1=\mathrm{e}^{-160 \cdot 5 \alpha} \\
& \alpha=0.0143 \mathrm{~min}^{-1}
\end{aligned}
$$

Substituting $\alpha$ into eqn (3), we obtain

$$
G_{13}(t)=G_{13, \mathrm{I}} \mathrm{e}^{-0.0143 t}
$$

where time $t$ is in minutes.

The relaxation model given by eqn (6) is now applied to the experimental results for load relaxation. The expression for central deflexion $f$ is given as $^{5}$

$$
f=\frac{a^{3} Q(t)}{(6 E I)}+\frac{a Q(t)}{2 A G_{13}(t)}
$$

where $a$ is half the span, $A$ is the beam cross-sectional area, and $I$ is its second moment of area relevant to bending of the beam; $Q(t)$ is the relaxed load after time $t . E$ is Young's modulus, which is governed mainly 
by fibres, and its relaxation can be ignored compared with $G_{13}(t)$. From the condition of constant central deflexion, $\mathrm{d} f / \mathrm{d} t=0$, the following equation is obtained:

$$
\frac{1}{G_{13}(t)} \frac{\mathrm{d} G_{13}(t)}{\mathrm{d} t}=\frac{1}{Q(t)} \frac{\mathrm{d} Q(t)}{\mathrm{d} t}\left\{1+\frac{A a^{2} G_{13}(t)}{3 E I}\right\}
$$

Combining eqns (3) and (8), and integrating, we have

$$
Q(t)=Q_{\mathrm{I}}(1+k) \mathrm{e}^{-\alpha t} /\left(1+k \mathrm{e}^{\alpha t}\right)
$$

where $k$ is a constant factor, given by

$$
k=A a^{2} G_{13, I} /(3 E I)
$$

By using the mean values of the dimensions of the specimen, the value of $k$ can be calculated. The prediction of the load in the time period of $60 \mathrm{~min}$ was

$$
\{Q(t)\}_{t=60}=0.958 Q(t)
$$

This means that the load reduction in $60 \mathrm{~min}$ is $4.2 \%$, which is in reasonable agreement with the experimental results (see Table 4), where the mean relaxation in load for the first hour was $5.8 \%$.

\section{CONCLUSIONS}

(1) The relaxation behaviour which occurred in three point bending tests on GRP beams constructed from glass in the form of chopped-strand mat was similar to that occurring in tests on pipe bends of the same material under in-plane bending.

(2) The manufacturing method involving hand lay-up resulted in bending and relaxation behaviour which was unsymmetric about the middle surface of the laminate.

(3) The undulating surface (i.e. that finally formed during the lay-up process) relaxed much faster than the smooth surface formed in the initial part of the lay-up process. This was especially so when the undulating surface was in tension, and there is so far no explanation for this behaviour.

(4) A relaxation mechanism was proposed assuming shear flow in the resin. Using this idea, together with an FEM analysis of the beam, resulted in a proposed method of calculating relaxation behaviour 
which gave results that were reasonably comparable with the experimental results for load and average surface strain. It involved the use of a modulus of rigidity varying with time in the following manner:

$G_{13}(t)=G_{13,1} \mathrm{e}^{-\alpha t}$

\section{ACKNOWLEDGEMENTS}

The experiments and the computation were carried out in the Applied Mechanics Division of the Department of Mechanical Engineering, UMIST. The authors extend their thanks to all who helped with the experimental work and its presentation, but particularly Mr P. W. Tennant for his patient assistance with the instrumentation.

\section{REFERENCES}

1. Kitching, R. and Myler, P., GRP smooth pipe bend behaviour under a variety of loads, Final Report to Polymer Engineering Directorate (SERC) Grant No. GR/C/53305, October 1985.

2. Kitching, R., Tan, A. L. and Myler, P., Tests to failure of GRP pipe bends under in-plane flexural loading, $I$. Mech. E. Conference 'Pipework design and operation', Paper C28/85, 1985, p. 21.

3. Barton, D. C. and Soden, P. D., Short term in-plane stiffness and strength properties of CSM reinforced polyester laminates, Composites, 13(1) (1982) 66-78.

4. Kitching, R., Tan, A. L. and Abumansour, T. M., The influence of through thickness properties on glass reinforced laminated structures, Composite Struct., 1(2) (1984) 105-151.

5. Gere, J. M. and Timoshenko, S. P., Mechanics of materials, 2nd edn, Brooks/Cole Engineering Division, 1984, 665. 